\title{
経肺圧に基づく換気設定により，体外式膜型人工肺を回避し た急性呼吸窮迫症候群の新生児例
}

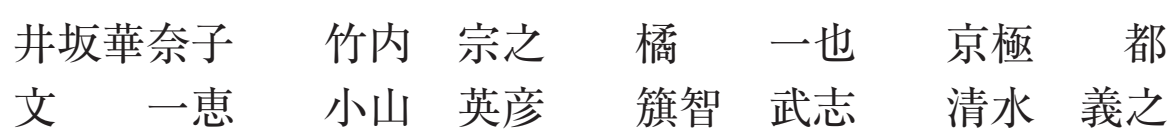

\begin{abstract}
要約：劇症型 $\mathrm{A}$ 群レンサ球菌感染症により敗血症性ショック, 急性呼吸窮迫症候群 (acute respiratory distress syndrome, ARDS) をきたした日齢20の新生児症例。低酸素血症が急速 に進行し, 経過中にプラトー圧 $28 \mathrm{~cm} \mathrm{H}_{2} \mathrm{O}, \mathrm{PEEP} 8 \mathrm{~cm} \mathrm{H}_{2} \mathrm{O}$ となり, 体外式膜型人工肺 (extracorporeal membrane oxygenation, ECMO) が考慮された。この時点で, 食道内圧を測 定し, 経肺圧を計算したところ, 最高経肺圧は $18 \mathrm{cmH}_{2} \mathrm{O}$ であった。Grasso らの報告 ${ }^{1)}$ に従い, 最高経肺圧が $25 \mathrm{cmH}_{2} \mathrm{O}, 1$ 回換気量が $6 \mathrm{ml} / \mathrm{kg}$ となるように, プラトー圧 $38 \mathrm{cmH}_{2} \mathrm{O}, \mathrm{PEEP}$ $14 \mathrm{~cm} \mathrm{H}_{2} \mathrm{O}$ に設定したところ, 低酸素血症は改善した。敗血症治療も奏功し, 8 日目に抜管, 13 日目にICUを退室した。急速に進行する重症 ARDSに対して経肺圧に基づく換気設定を行 い, ECMOを回避できた。
\end{abstract}

Key words: (1) esophageal pressure, (2) severe invasive streptococcal infection, (3) neonates

\section{はじめに}

胸郭コンプライアンスの低下した急性呼吸窮迫症候 群 (acute respiratory distress syndrome, ARDS) で は, 経肺圧測定を行うことで, 適切な人工呼吸器設定 圧の調整が可能となり，過剩な圧や圧不足による肺傷 害や無気肺を防ぐことができる可能性があり，経肺圧の モニタリングは重要である。成人ARDSに対して経肺 圧測定に基づく換気設定の調整を行い, 不必要な体外式 膜型人工肺 (extracorporeal membrane oxygenation, ECMO）を回避したという Grasso らの報告1)もある。 新生児期に発症したARDSに対して同様の調整を行 い, ECMOを用いずに生存退院できたと考えられる症 例を経験したので報告する。

\section{症 例}

日齢20の男児。チアノーゼが出ていることに父親 が気付き, その後呼吸が停止したため人工呼吸を行っ た。すぐに呼吸は再開したが，その時に右腕が脱力状 態で右前胸部の発赤・腫脹に気が付いて救急要請し前
医に搬送され，気管挿管後に当院搬送となった。

既往歴: 在胎週数不明, 妊娠経過不明, 自宅出生。 出生体重 $2,540 \mathrm{~g}$ 。

家族歴：特記事項なし。

入院時現症：体重 $3,193 \mathrm{~g}$ 。GCS 4点 (E2VTM1)（鎮 静薬未使用), 呼吸数 $48 / \mathrm{min}$, 圧規定式アシスト換気 (プ ラトー圧 $20 \mathrm{cmH}_{2} \mathrm{O}$, PEEP $5 \mathrm{cmH}_{2} \mathrm{O}$, 換気回数 $30 /$ $\min$ )下で, 1 回換気量 $20 \mathrm{~m} l, \mathrm{P} / \mathrm{F}$ 比 175 , oxygenation index (OI) 5.8 。心拍数 $156 / \mathrm{min}$, 血圧 $70 / 35 \mathrm{mmHg}$, 瞳孔径 (左 $2 \mathrm{~mm}$, 右 $2 \mathrm{~mm}$ ), 対光反射あり, 体温 $38.0^{\circ} \mathrm{C}$ 。 血液検查をTable 1に示した。胸部X線撮影では, 無 気肺を認めていた。

\section{経 過}

入室時, 右上腕から前腕は硬性浮腫で変色し, 腫大 は右腋窝から右前胸部, 右側胸部, 右側腹部まで連続 していた。仙骨部領域も発赤膨隆し, 下腿に斑点状の 発疹を認めた。CTでは皮下に多発性に液体貯留を認 め (Fig. 1), 前胸部皮下腔を穿刺すると膿汁が引けた。 蜂窩織炎，または腋下リンパ管の感染を疑い，スルバ 
Table 1 Laboratory data on admission

\begin{tabular}{|c|c|}
\hline \multicolumn{2}{|l|}{ Hematology } \\
\hline WBC & $6.2 \times 10^{3} / \mu l$ \\
\hline $\mathrm{RBC}$ & $3.4 \times 10^{6} / \mu l$ \\
\hline $\mathrm{Hb}$ & $11.0 \mathrm{~g} / \mathrm{d} l$ \\
\hline Plt & $8.4 \times 10^{4} / \mu l$ \\
\hline \multicolumn{2}{|c|}{ Coagulation factors } \\
\hline PT-INR & 1.46 \\
\hline APTT & $41 \mathrm{sec}$ \\
\hline Fib & $260 \mathrm{mg} / \mathrm{d} l$ \\
\hline FDP & $235 \mu \mathrm{g} / \mathrm{d} l$ \\
\hline \multicolumn{2}{|c|}{ Blood biochemistry } \\
\hline TP & $4.6 \mathrm{~g} / \mathrm{d} l$ \\
\hline Alb & $1.8 \mathrm{~g} / \mathrm{d} l$ \\
\hline AST & $44 \mathrm{IU} / l$ \\
\hline ALT & $15 \mathrm{IU} / l$ \\
\hline $\mathrm{LDH}$ & $715 \mathrm{IU} / l$ \\
\hline BUN & $11.8 \mathrm{mg} / \mathrm{d} l$ \\
\hline $\mathrm{Cr}$ & $0.14 \mathrm{mg} / \mathrm{d} l$ \\
\hline $\mathrm{Na}$ & $117 \mathrm{mmol} / /$ \\
\hline $\mathrm{K}$ & $4.3 \mathrm{mmol} / \mathrm{l}$ \\
\hline $\mathrm{Cl}$ & $82 \mathrm{mmol} / \mathrm{l}$ \\
\hline $\mathrm{Ca}$ & $8.9 \mathrm{mg} / \mathrm{d} l$ \\
\hline T-Bil & $3.3 \mathrm{mg} / \mathrm{d} l$ \\
\hline CK & $248 \mathrm{U} / l$ \\
\hline CRP & $23.8 \mathrm{mg} / \mathrm{d} l$ \\
\hline \multicolumn{2}{|l|}{ Blood gas } \\
\hline $\mathrm{pH}$ & 7.35 \\
\hline $\mathrm{PaO}_{2}$ & $70.1 \mathrm{mmHg}$ \\
\hline $\mathrm{PaCO}_{2}$ & $43.3 \mathrm{mmHg}$ \\
\hline $\mathrm{HCO}_{3}{ }^{-}$ & $23.6 \mathrm{mmol} / \mathrm{l}$ \\
\hline $\mathrm{BE}$ & $-1.4 \mathrm{mmol} / \mathrm{l}$ \\
\hline Glucose & $80 \mathrm{mg} / \mathrm{d} l$ \\
\hline Lac & $22 \mathrm{mg} / \mathrm{d} l$ \\
\hline
\end{tabular}

Alb, albumin; Fib, fibrinogen; Lac, lactate; TP, total protein.

クタム/アンピシリン (sulbactam/ampicillin, SBT/ $\mathrm{ABPC}$ )と免疫グロブリンの投与を開始し, 前胸部か ら上腕部にかけての排膿ドレナージ術を施行した。術 直後から収縮期血圧 $50 \mathrm{mmHg}$ を維持することが困難 な敗血症性ショックに陥り, 抗菌薬をバンコマイシ ン・メロペネムに変更し, 大量の輸血・輸液とカテコ ラミン (ドブタミン $9.6 \mu \mathrm{g} / \mathrm{kg} / \mathrm{min}$, ノルエピネフリ ン $0.18 \mu \mathrm{g} / \mathrm{kg} / \mathrm{min})$ を投与したが, 低血圧とそ尿が続 き全身の浮腫は著明となった。1回換気量や $\mathrm{SpO}_{2}$ の 低下, 淡赤色の気道分泌物が多量に回収, 胸部 X線に て両側肺透過性低下を認め, 敗血症に伴うARDS と診 断した。術前 $\mathrm{P} / \mathrm{F}$ 比は 198 , OI 7.5 であったが, 術直

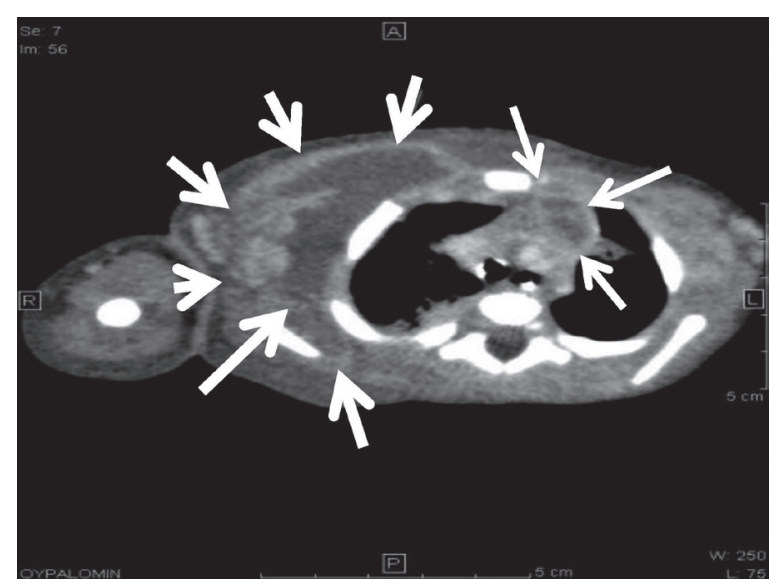

Fig. 1 Neonate with septic shock and acute respiratory distress syndrome caused by invasive group A streptococcal infection

CT scan shows abscesses in subcutaneous tissues and the mediastinum(arrows).

後はプラトー圧 $28 \mathrm{cmH}_{2} \mathrm{O}, \operatorname{PEEP} 8 \mathrm{cmH}_{2} \mathrm{O}$, 換気回 数 $30 / \mathrm{min}$ で, 1 回換気量 $18 \mathrm{ml}, \mathrm{P} / \mathrm{F}$ 比 $122, \mathrm{PaCO}_{2}$ $74 \mathrm{mmHg}$ であった。Surviving Sepsis Campaign Guidelines (SSCG) 20122) ガイドラインに準じ, 気道 内圧を上げず, 換気回数を $40 / \mathrm{min}$ に上げて対処して いた。術後 1 時間には, 1 回換気量 $12 \mathrm{ml}, \mathrm{P} / \mathrm{F}$ 比は 54 , $\mathrm{PaCO}_{2}$ は $72 \mathrm{mmHg}$, OIは31となり, 血圧も低下, ARDSの急激な進行でECMOが考慮されるに至った。 まずは酸素化を改善する必要があったので, 後述の方 法で食道内圧モニ夕を開始した。Grassoらの報告1)に 基づき経肺圧を計算したところ, 最高経肺圧は 18 $\mathrm{cm} \mathrm{H}_{2} \mathrm{O}$ であった。 $25 \mathrm{~cm} \mathrm{H}_{2} \mathrm{O}$ 以下の最高経肺圧は肺 傷害を増悪させないと考えて, 最高経肺圧を 25 $\mathrm{cm} \mathrm{H}_{2} \mathrm{O}$ とて, プラトー圧 $38 \mathrm{cmH}_{2} \mathrm{O}, \mathrm{PEEP} 14$ $\mathrm{cmH}_{2} \mathrm{O}$ に設定した。結果, 1 回換気量は $19 \mathrm{ml}, \mathrm{P} / \mathrm{F}$ 比 は84, $\mathrm{PaCO}_{2}$ は $51 \mathrm{mmHg}$ と改善を認めた (Fig. 2)。 その後, 持続的な $\mathrm{P} / \mathrm{F}$ 比の上昇と血行動態の改善を認 め, 比較的速やかに人工呼吸器条件を下げることがで きた。

穿刺排膿した膿汁と, 血液培養からStreptococcus pyogenes (A 群 $\beta$ 溶血性レンサ球菌) が同定された。菌 の同定に加えて, ショック状態, ARDS, 軟部組織腫 脹から, 劇症型 $\mathrm{A}$ 群 $\beta$ 溶血性レンサ球菌による多発膿 瘍, 骨髄炎, 関節炎と診断した。薬剤感受性結果は良 好で, ABPCとして最大量を継続させた。軟部組織・ 骨髄への移行性を考慮しクリンダマイシンを追加し た。炎症反応は遷延したが，4日後に仙尾部の穿刺排 膿および, 右肘・右肩・両股関節, 腸腰筋膿瘍の排膿 ドレナージ術を施行した際の培養結果はいずれも陰性 

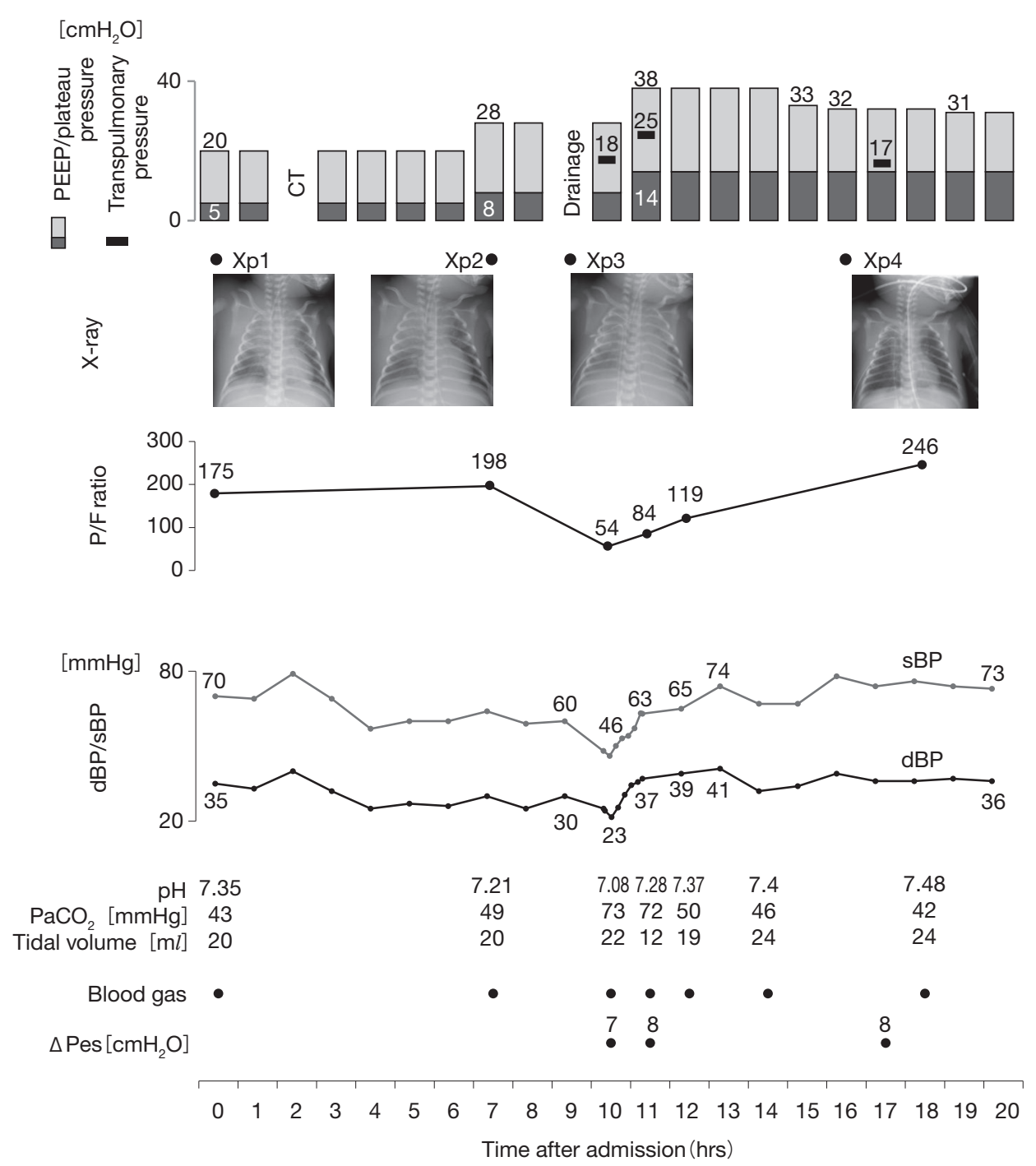

Fig. 2 Clinical course for the 20 hours following admission to the PICU Pes, esophageal pressure.

を示した。

その後8日目に抜管, 13 日目に酸素なしで退室し た。静脈内抗菌薬投与 4 週間とアモキシシリン内服投 与を 4 週間行った。CRPは27日目に陰性化し, 膿瘍は 全て消失した。右肘関節の可動域制限はあるが, 発達 · 発育ともに順調である。

\section{食道内圧測定方法}

小児食道カテーテル $(6 \mathrm{Fr}$, アイ・エム・アイ 用し, 筋弛緩薬使用下で自発呼吸のない状態で操作し た。カテーテルは鼻腔から胃内まで挿入た後, 引き 抜いて (胸部X線写真では, 下部食道位置で), 留置し た。18 G末梢静脈留置針の外筒を食道カテーテルの 途中の切断端内腔に隙間なく差し达み, トランス デューサ (エドワーズライフサイエンス, 米国)に接
続。観血血圧ケーブル, 生体情報モニタ（フィリップ ス, オランダ)に接続して, 圧波形拈よび測定数值を 表示させた。 $0.3 \mathrm{ml}$ の空気を入れてバルーンを膨らま せた。位置確認のための閉塞試験は, 低酸素血症が進 行する状況では行えなかった。その代わりに，心尖拍 動波形が含まれていることと胸部X線写真で位置を 確認した。記録は, 最大食道内圧と最低食道内圧の差 $(\mathrm{mmHg})$ で行い, $\mathrm{cmH}_{2} \mathrm{O}$ 換算を行った值を食道内圧 変化值 $(\Delta \mathrm{Pes})$ とした。最高経肺圧 $\left(\mathrm{P}_{\mathrm{L}}\right)$ の算定は, Grasso らの提唱する方法1)から, $\mathrm{P}_{\mathrm{L}}=$ プラトー圧 $\times$ $(\mathrm{PC}-\Delta \mathrm{Pes}) / \mathrm{PC}$ を利用した (pressure control, $\mathrm{PC})$ 。

\section{考 察}

本症例は敗血症性ショックに伴うARDSで, SSCG 2012 の勧告に基づく人工呼吸管理中に, 重度の低酸素 
血症へ急速に進行した。身体所見および CT 所見で胸 壁の浮腫と腸管浮腫による腹部膨隆が明らかで, 胸郭 コンプライアンスが低下し, 人工呼吸器設定圧に対し て肺にかかる圧 (経肺圧) が低くなっていることが考 えられたため, 食道内圧測定を行った。Talmorらは, 食道内圧測定に基づきPEEPを調整する方が, ARDS ネットワークが推奨する標準治療に基づいて PEEPを 調整するよりも，酸素化やコンプライアンスが有意に 改善すると報告している3)。しかし, 小児では, バルー ンのガス量などに大きく食道内圧が依存してしまうた め, 食道内圧の絶対值を利用することは難しい4)。そ こで我々は， $\Delta$ P esを利用するGrassoらの方法1)を利 用した。人工呼吸器設定変更前に $\Delta$ Pesを測定し, 前 述の式を用いて最高経肺圧を算出した。これが 25 $\mathrm{cmH}_{2} \mathrm{O}$ 以下であれば, このときに測定された $\Delta \mathrm{Pes}$ と $\mathrm{PC}$ の比から, 経肺圧が許容上限の $25 \mathrm{~cm} \mathrm{H}_{2} \mathrm{O}$ になる ようなプラトー圧を予測する。そのプラトー圧が予測 值になるように, PCはそのままでPEEPを上げる。 その後プラトー圧はそのままに 1 回換気量が $6 \mathrm{ml} / \mathrm{kg}$ になるようにPEEPを徐々に低下させた。人工呼吸器 設定変更後に, 再度 $\Delta$ Pes を測定して最高経肺圧を算 出し, $25 \mathrm{cmH}_{2} \mathrm{O}$ 以下であることを確認した。

経肺圧計算上の問題点として, 前述の算定式でエラ スタンス比が常に一定であると仮定していることがあ る。また, 厳密には経肺圧も肺全体で均一ではない5 ため, 部分的に高い経肺圧が生じている可能性もある。 したがって, 本症例でも酸素化の改善が確認され次第, プラトー圧を下げることを考え換気調整した。

重篤なARDS症例では, 高頻度振動法 (high frequency oscillation, HFO) やECMO, 筋弛緩薬, 腹 臥位,一酸化窒素が考慮される。本症例では, HFOは 新たな機種に交換しなければならない, コンプライア ンスや 1 回換気量のモニタリングができないなどの理 由で使用しなかった。ECMOは酸素化が致死的な場 合に適応となるが, 本症例では新生览であり重症例で の脳出血の可能性は成人より経験的に高いこと, 抗凝 固によるドレナージ部位からの出血が広範囲で難渋す ること, ECMO回路への吸着や循環血液量増加などで 抗菌薬の適正量が不明瞭になること, そしてカニュー レのアクセスサイトが限られていることなどから, $\mathrm{ECMO}$ 上りも経肺圧に基づく換気法がより安全であ ると考えた。筋弛緩薬は, 大きな自発呼吸による経肺 圧の上昇を抑制することにより, 人工呼吸器関連肺傷 害を抑制できると考え, 本症例でも 22 時間持続投与 した。腹臥位は, 循環が不安定で実施不可能であった。
一酸化窒素も実施しなかったが, 極期のアシドーシス 改善に伴う血圧上昇は肺高血圧病態を示唆するため, 使用適応はあった可能性がある。

劇症型 $\mathrm{A}$ 群レンサ球菌感染症の新生児 39 例の後方 視的検討がなされた 2004 年の報告6)では, 人工呼吸管 理を $54 \%$ の患者で行い, 死亡率は $31 \%$, 死亡の $67 \%$ は 24 時間以内に発生していた。本症例も, 新生児期の発 症で文献の経過同様, 症状の経過は急速であった。こ のような状況下でも, 食道内圧カテーテルは比較的速 やかに挿入でき, $\mathrm{ECMO}$ 導入を決める前に肺保護換気 を考虑した人工呼吸器設定を検討する上で有用であっ たと考えられる。

\section{結 語}

劇症型 $\mathrm{A}$ 群 $\beta$ 溶血性レンサ球菌感染症により敗血症 性ショック㧍よびARDSを呈した新生児の全身管理 を経験した。急速に進行する重度のARDSに, 食道内 圧測定に基づいて最高経肺圧を考慮した換気設定を行 うことで, ECMOを回避しつつ救命できたと考えられ た。

本稿の要旨は, 第60回日本集中治療医学会近畿地方会 (2015年, 大阪)で発表した。

\section{著者のCOI (conflicts of interest) 開示}

竹内宗之：Covidien（米国）より研究費を得た。 その他, 本稿の全ての著者には規定されたCOIはない。

\section{文 献}

1) Grasso S, Terragni P, Birocco A, et al. ECMO criteria for influenza A (H1N1)-associated ARDS: role of transpulmonary pressure. Intensive Care Med 2012;38:395-403.

2) Dellinger RP, Levy MM, Rhodes A, et al; Surviving Sepsis Campaign Guidelines Committee including The Pediatric Subgroup. Surviving Sepsis Campaign: international guidelines for management of severe sepsis and septic shock, 2012. Intensive Care Med 2013;39:165-228.

3) Talmor D, Sarge T, Malhotra A, et al. Mechanical ventilation guided by esophageal pressure in acute lung injury. N Engl J Med 2008;359:2095-104.

4) Coates A, Stocks J, Gerhardt T. Esophageal manometry. In: Stocks J, Sly D, Tepper R, editors. Infant respiratory function testing. New York: Wiley-Liss; 1996. p. 241-58.

5) Mead J, Takishima T, Leith D. Stress distribution in lungs: a model of pulmonary elasticity. J Appl Physiol 1970;28:596-608.

6) Miyairi I, Berlingieri D, Protic J, et el. Neonatal invasive group A streptococcal disease: case report and review of the literature. Pediatr Infect Dis J 2004;23:161-5. 


\section{Abstract}

Lung protection strategy based on transpulmonary pressure could repel the need for extracorporeal membrane oxygenation in a neonate with severe acute respiratory distress syndrome

Kanako Isaka, Muneyuki Takeuchi, Kazuya Tachibana, Miyako Kyogoku, Kazue Moon, Hidehiko Koyama, Takeshi Hatachi, Yoshiyuki Shimizu

Department of Intensive Care Medicine, Osaka Women's and Children's Hospital

840 Murodo-cho, Izumi, Osaka 594-1101, Japan

This report presents the case of a neonate with septic shock and acute respiratory distress syndrome (ARDS) caused by invasive group A streptococcal infection. Mechanical ventilation was performed with plateau pressure of $28 \mathrm{cmH}_{2} \mathrm{O}$ and PEEP of $8 \mathrm{cmH}_{2} \mathrm{O}$. However, progressive hypoxemia continued and extracorporeal membrane oxygenation (ECMO) was considered. At this point, esophageal pressure was measured and transpulmonary pressure was calculated as 18 $\mathrm{cmH}_{2} \mathrm{O}$. Based on previous research indicating that transpulmonary pressures of $\leq 25 \mathrm{cmH}_{2} \mathrm{O}$ does not exacerbate pulmonary injury, the plateau pressure was increased to $38 \mathrm{cmH}_{2} \mathrm{O}$ and PEEP to $14 \mathrm{cmH}_{2} \mathrm{O}$. Hypoxemia improved, septic shock was treated successfully, and the neonate was extubated on day 8 and discharged from the ICU on day 13 . This case suggests that ECMO can be avoided in neonates with rapidly progressive severe ARDS by adjusting ventilation support based on transpulmonary pressure.

Key words: (1) esophageal pressure, (2) severe invasive streptococcal infection, (3) neonates

J Jpn Soc Intensive Care Med 2017;24:332-6. 